\title{
Selective Multiculturalism? Symbols of Ethnic Identity and Core Values Theory
}

\author{
Susan Kennedy \\ School of Education, Faculty of Social Science, University of Adelaide \\ Susan.kennedy@adelaide.edu.au, sfkennedy@gmail.com
}

Doi:10.5901/jesr.2015.v5n1p249

\begin{abstract}
This paper is a retrospective critique of the sociological theory of Symbols of Ethnic Identity and Core Values developed by Jerzy Smolicz, and the social milieu in which it took place. The theory claimed to be based on the inductive, humanistic sociology approach of Florien Znaniecki. It was concerned with ascribing language and ideological values to the identity of students from migrant families in Australia. It proposed that some ethnic groups were more 'language centred' than others. This formed the basis for the promotion by Smolicz of the language and cultural rights of some ethnic groups above others. Alongside the development of the theory, Smolicz was deeply involved in multicultural politics and language policy debate in Australia. The development of theory was based on data that was weaker than one might expect and shaped by his engagement in radical political discourse. Smolicz's dual contribution indicates a selective multiculturalism was at play.
\end{abstract}

Keywords: Ethnic, minority, identity, values, theory, multiculturalism, education

\section{Introduction}

Symbols of Ethnic Identity and Core Values Theory are two theoretical developments in the theory of social science credited to Jerzy Smolicz, a social scientist at the School of Education at The University of Adelaide. He made a highly respected contribution to the study of ethnic identity and language policy in Australia, at the height of Australia's 'multicultural society' policy era. He was a prolific author in the social sciences and education, with interests in language, culture and nationalism. The work was inspired by the social and cultural theory of Florien Znaniecki (for example Znaniecki, 1934; Znaniecki, 1952; Znaniecki, 1969), mostly concerned with ascribing language values to the identity of students from migrant families in Australia. Following Florian Znaniecki's (1934) focus on inductive method, Smolicz (1974) claimed to employ a humanistic sociology interpretive approach. This article reviews Symbols of Ethnic Identity and Core Values theory in the broader context of Smolicz's political discourse on Australian society, the nation's language policy and education system. It is presented in two parts. In Part 1, I analyse Smolicz's work on Native Tongues and Family Structures as Symbols of Ethnic Identity (Smolicz in Halas, 2002), which proposed innovations to the classification of social systems and ideological values. The theory refined conceptions of migrant families, including the notion of the extended migrant family units and a social collective ideology shared among their members. In Part 2, I analyse Core Values theory, for which the researcher was best known, and the intersection of this theory with discourse on the rights of certain ethnic groups, from which arose a form of selective multiculturalism. A review of much of the evidence used to support theoretical developments casts doubt on the nature of claims that the theory was inductive, arising from the data presented. The work serves as a snapshot in time that reveals much about the influence of educational researchers on the development of Australia's language policy, with a more dynamic, reciprocal and authentic vision of cultural identity emerging.

\section{Symbols of Ethnic Identity}

In Native Tongues and Family Structures as Symbols of Ethnic Identity (Smolicz in Halas, 2002) Smolicz introduced a new theory about migrant family structures and networks, based on his previous work on Core Values. A proponent of Florien Znaniecki's humanistic sociology, he introduced a new theoretical framework to distinguish between family structure and ideology of particular ethnic groups and Anglo-Saxon and Anglo-Celtic Australians (Smolicz, 1974). He developed the framework by conducting a review of some ten research papers drawn from the School of Education, including 6 published and 4 apparently unpublished works. Most, if not all, of the studies had been conducted by himself, his colleagues and research students. Smolicz sourced a continual supply of data from students at the School of 
Education who were asked to fill out questionnaires for research students, many of whom based their theses on the same data.

Smolicz presented the new theoretical constructs in two simple tables, labelled the Classification of Social Systems (Smolicz in Halas, 2002, p.106) and Ideological Values and Social Systems in Different Societies (Smolicz in Halas, 2002, p.112). According to the first theoretical innovation, the classification of social systems, Non-Anglo-type migrant families exhibited particular relationships and behaviours that Anglo-Saxon and Anglo-Celtic Australians did not. He proposed that this included the ability for Non-Anglo-Saxon and Non-Anglo-Celtic people to instantaneously activate certain cultural values. By way of example, he claimed that unknown relatives from certain ethnic groups could travel to Australia to attend 'special occasions' such as weddings and funerals, and on this basis, they achieved immediate primary membership to the family group (Smolicz in Halas, p.108).

For the second theoretical innovation, Smolicz developed his theory of Ideological Values and Social Systems in Different Societies by drawing on multiple sources but mainly inspired by Hofstede (1994) Cultures and Organisation: Intercultural Cooperation and its Importance for Survival (Smolicz in Halas, 2002). He proposed that where normally members of migrant families exhibited individualist functioning at the secondary relationship level (beyond the immediate family), that migrants 'accommodated themselves to minority conditions in Australia,' and developed a 'more intimate ethnic complexion' (Smolicz in Halas 2002, p.113). This complexion transformed functioning at the secondary level from individualist to collectivist. Thus, Smolicz had attempted to describe Non-Anglo-type societies in Australia as collectivist at both the primary and secondary levels.

Having introduced Smolicz's theoretical developments, I will analyse them in detail as they appear in Native Tongues and Family Structures as Symbols of Ethnic Identity (Smolicz in Halas, 2002).

\subsection{The Classification of Social Systems}

Describing primary and secondary relationships among individuals and groups, Smolicz (in Halas, 2002) proposed that,

The distinction between primary relations... as close, intimate and on-going, and secondary relations, as more distanced, formal and restricted, on the other, adds another dimension to the understanding of social systems

(Smolicz in Halas, 2002, p.106).

Next, the distinction among Anglo-Saxon and Anglo-Celtic Australians and Polish and Italian Australians was described. Contrasting a nuclear family type with a 'ramified' extended family,

When a nuclear family constitutes a primary group system, almost invariably all of its members are included in one another's primary personal systems. In contrast, in a ramified extended family, some members may not be personally known to all the other members, especially in a situation where the family is scattered between Australia and the country of origin

(Smolicz in Halas, 2002, p.108).

He did not make it clear whether or not these additional family members were classified to the primary group system or the secondary personal system. According to Smolicz, such family members were,

... potential members of primary group systems so that the family members who may at the moment be personally unacquainted, would become actual members when they had occasion to meet a family reunion held on special occasions, weddings, funerals or other cross-continental gatherings

(Smolicz in Halas, 2002, p.108).

The discussion of how the primary and secondary social system works was complicated by the lack of explanation as to who was typically ascribed to these categories, although it was presented as a typical model. Anglo-heritage families were described as small nuclear, emotionally distant and individualist; minority ethnic-heritage families were described as large, intimate, caring and collectivist. But he did not say whether their membership to the primary system was primary or secondary (Smolicz in Halas, 2002, p.106). Secondary group systems were described as being in the broader realm of the social world, but he failed to distinguish between members of a secondary personal and secondary group system. Instead, he moved directly to comparisons of individualism and collectivism. There was also a lack of explanation as to where in the system distant relatives were positioned before they joined the primary system of their relatives in Australia (Smolicz in Halas 2002, p.108). This seems surprising when data from ten studies describing 
participant's family experiences was reviewed in the article. The only link I could find that positioned members in a category was a comment by Smolicz that some minority ethnic-heritage respondents found Anglo-heritage families withdrawn and distant, such that 'they were associated in their minds with secondary social relationships,' (Smolicz in Halas 2002, p.112).

Smolicz seems to have relied on an interpretation of 'emotional detachment' (Smolicz in Halas 2002, p.109) to characterise Anglo-Saxon and Anglo-Celtic Australians based on quotes from previous studies. In the interpretation of emotional detachment in Native Tongues and Family Structures as Symbols of Ethnic Identity (Smolicz in Halas, 2002) the variables seemed to be confused. Quoting findings and commentaries from previous studies by himself and his colleagues, individualistic and independent behaviours or values cited by participants were interpreted as amounting to emotional detachment (see Smolicz in Halas 2002, p.108-109). It is not clear why these variables were interpreted as one in the same. The only indication of emotional detachment in the ten studies he analysed that was discussed in his book chapter was one participant talking about her parents sitting down to a formal meal at the dinner table (quoted in Smolicz in Halas 2002, p.108 in the second quote from study 3a). The only clear statement that was quoted by the researcher regarding emotional detachment such that (in the third quote from Study 3a),

'Anglo-Saxon values of self-reliance, independence and personal autonomy and individualism, which fostered emotional distance exhibited by so many English families'

(Smolicz in Halas, 2002, p.108).

The interpretive connection between independence fostering emotional distance was not revealed. All in all, this aspect of the theory justifying differences between Anglo-Saxon and Anglo-Celtic Australian families looks somewhat stereotypical rather than drawn from the data.

Before moving on to the second theoretical development proposed in Smolicz, Native Tongues and Family Structures as Symbols of Ethnic Identity (Smolicz in Halas, 2002) a note on the historical context of the term used by Smolicz, 'family reunion' is relevant. This term was commonly related to a broader conception of 'family reunion' in migration at the time, widely known among members of Australian society. The family reunion migrant visa was a very popular and successful way for families to migrate together (Foster and Stockley, 1988). It enabled whole family units to migrate to Australia in an internally coordinated fashion after the successful immigration of the first member.

\subsection{Individualist and Collectivist Ideology in Different Societies}

The second theoretical innovation in Native Tongues and Family Structures as Symbols of Ethnic Identity (Smolicz in Halas, 2002) was inspired by Hofstede's (1994) findings on Individualism Index Values (IDV). Hofstede (1994) conducted a comparative study of 50 countries. The index was used by Smolicz (in Halas, 2002) to compare individualism and collectivism among ethnic groups in Australia. As I outlined in the introduction to Part 1 above, it was claimed that families from minority cultures adapting to Australia,

'accommodated themselves to minority conditions in Australia. Social conditions had come to assume a more intimate ethnic complexion'

which,

'radiates from their collectivist family to the ethnic group as a whole, as if the latter were simply a very large extended family,'

(Smolicz in Halas 2002, p.11. My italics.).

The belief that this capacity could only be accorded to certain groups was qualified by,

'Not all ethnic groups have been equally adept at radiating the collectivist family ethos into their ethno-specific secondary structures,'

(Smolicz in Halas, 2002, p.113. My italics.)

because the Catholic school system was hindering the ethnic school initiatives of the Italian and Polish communities (Smolicz in Halas, 2002).

The notion of 'radiating' a collective intimacy into the community was put forward as the reason for the assignment 
of collectivist ideological values to the primary social system of ethnic minorities in Australia. This further reinforced Smolicz's claim to primary group membership by distant, unknown relatives who maintained only occasional contact in the Classification of Social Systems. The problem of how the actual social mechanisms of 'radiating' worked, whereby the collectivist ideology normally applied to the primary social system was transferred to the secondary social system. The classification was descriptive but arbitrary, for the evidence presented on family structures recounted life experiences within small families only. In Native Tongues and Family Structures as Symbols of Identity (Smolicz in Halas, 2002) there were not any recounts of large, ethnic minority families that one might expect to substantiate the theory of collective family structure or ideology. Respondent data put forward offered recounts of some grandparents, an aunt and a few first cousins while much of the data presented on second-generation migrant respondents was confined to the nuclear family unit, referring to child-parent relationships. Only two excerpts described interaction with grandparents in minority Ethnic-heritage families, one of them seemed to be commentary about Italians by the researcher from the original study (Smolicz in Halas 2002, p.109, study 2b). The other was by an Anglo-heritage respondent talking about visiting her friend, where here friend's grandparents and aunt lived (Smolicz in Halas 2002, p.110, study 3a).

For both theoretical constructs then, there was no evidence, of how these processes of transitioning from one social category to another social category actually worked. This was surprising because Smolicz had mined data from ten previous studies. The actual social mechanisms were unexplained, whereby unknown family members would become known each other only for 'special occasions,' would suddenly qualify as primary family members and maintain their roles as 'close, intimate and on-going' members of the primary group (Smolicz in Halas 2002, p.106). Based on the definition of primary relations (Smolicz in Halas 2002, p.106) the example in the social system of the extended family (Smolicz in Halas 2002, p.108) crossing the categories of the group system was implausible, because the unknown family member example was defined by virtue of having no continuing social bond with the primary family. Without further explanation or evidence of how this process of transitioning between groups actually took place, the theory conformed to stereotypes. In terms of evidence derived from data, the theory was weak.

Smolicz did not consider exploring whether or not family gatherings for milestone family functions of the same nature, occurred in Anglo-Saxon and Anglo-Celtic Australian families. We might wonder, if the same criteria for group membership were applied to different ethnic groups and not just particular ones, would it have qualified unknown members of Anglo-Saxon and Anglo-Celtic Australian families, as exhibiting a primary group social systems when they showed up en masse at weddings and funerals? We will never know, because it was of no interest to Smolicz.

Next, he applied his theoretical developments to investigate to what extent these contrasting family systems were evident in the use of minority languages. He did this by reviewing excerpts of the ten articles and quoting respondent recounts of their use of their first language. He found that there were differences in Northern and Central Italians compared to and Southern Italian's uptake of English and their maintenance of standard Italian and regional dialects. Italian respondents from the North and Central region attempted to master English quickly, but Italian respondents from the South tried to maintain their local dialect, which was associated with a closer level of family cohesion. The only explicit connection between language maintenance and family cohesion put forward by Smolicz was the data from one respondents, who said that the dialect did not disappear due to the strength of the family unit from Study 2a (Smolicz in Halas, 2002, p.119). He cited Clyne's (1991) assertion that dialect is 'intricately associated with family cohesion,' (Smolicz in Halas, 2002, p.119).

It is remarkable that Smolicz did not perceive in review across ten studies, any tension experienced by students who had to cope with expectations for high academic achievement at school. This expectation would likely have influenced the rate of English language acquisition and the time and effort students could invest in retaining the first language. The expectation for high achievement in literacy was exhibited by Latvian respondents who valued the mastery of the Latvian language to a literary level across the second and third generations since immigration, over and above everyday language use and above family closeness (Smolicz, Secombe and Hudson 2001, cited in Smolicz in Halas, 2002, p.121). Smolicz read the Latvian values on a high level of language mastery as a singularly nationalist symbol of the global Latvian diaspora. He did not entertain the possibility of alternative or additional interpretations, that perhaps the high value on language literacy held by families was transferable to Latvian student's performance in education in Australia, real or aspirational.

Indeed, the need for migrants to maintain their language was the most important symbol of cultural identity for Smolicz, who interpreted the uptake of English language as something of a hostile demand, a 'penetrating' (Smolicz in Halas 2002, p.119) method of assimilation. It would have been worthwhile exploring the experience family closeness maintained during the transnational migration process in which language adaptation became inevitable for young 
students and for some of their parents, because they had no choice but to learn English. There might have been positive motivations for the uptake of English language, such that it was the language of the general curriculum in Australian schools, for acceptance into a new peer group of friends and of practical significance to daily life. Smolicz did not explore these issues but he bemoaned that in Australian schools, 'English dominates the scene' (Smolicz in Halas 2002, p.23).

Smolicz seems to have made an error in his analysis because he argued only from the negative. By focusing on perceived cultural losses and failing to look for cultural gains and the advantages of bilingualism, his pre-eminent concern for migrant students to access teaching of their native language in schools, remained fixed. This preoccupation detracted from the development of theory that he set out to make at the beginning of his article about minority group family structures. If minority group members belonged to and were supported by primary and/or collectivist family group structures the size of their entire ethnic groups, while other Australians were characterised by individualism, isolation and (tiny by comparison) nuclear families, it is difficult to see that new arrivals in Australia were so isolated and outnumbered, such that their cultural identity was on the verge of extinction (this claim is explored further below). In trying to establish theoretical constructs where migrants could claim among their primary family members relatives living in their country of origin whom they had never met before (and did not intend to meet regularly) the claim to very large extended families comprising an entire ethnic group and collectivist ideological values, Smolicz revealed a new, perhaps unintended finding: ethnic cultural networks in Australia were in fact more capable of providing social and emotional support to their families than were 'mainstream' Australians from British backgrounds who were, according to the researchers, emotionally distanced, superficial and detached (Smolicz in Halas 2002, p.108-109).

\section{Core Values Theory as Selective Multiculturalism}

To better understand how Smolicz could present such weak theory on social systems and ideology, where crucial transitions between categories in social systems were not explained but appeared speculative or stereotypical, Smolicz's earlier claim to Core Values theory is of key relevance. Together with the process of theorisation I have just described, it reveals much about the methods used researchers to developed their theory and perhaps, a lack of pause for critical reflection. Core Values theory reveals a larger project carving out conceptual space for certain ethnic groups to make claims on funding for languages education, where self-reported value of one's native language was used to establish the concept of 'language-centred' cultures (Smolicz, 1991, p.44).

Smolicz believed it was crucial for native minority languages to be taught in schools as a symbol of ethnic identity. This was to ensure cultural maintenance and survival for certain ethnic groups (Smolicz in Halas, 2002; Smolicz, 1979; Smolicz, 2010) as a strategy for resistance against 'assimilationist pressures' (Smolicz in Halas, 2002, p.120). But in focusing on language as a symbol of ethnic identity (Smolicz in Halas, 2002), he did not interpret the research respondent's family's value on language literacy as transferrable to other areas of education. Nor did he care to explore the communicative or transnational contexts that existed between respondents with other Australians of any ethnic background. Smolicz was unable to figure that all minority language speakers might have a claim to native language tuition. This was where the researcher's attachment to the nation's multicultural egalitarian ethos, fell away. His vision did not see all Australian students becoming multilingual as part of a multicultural society, strong in intercultural communicative competence, nor all students receiving tuition in their native language in schools. This was a selective multiculturalism.

Smolicz's interpretation of the threat of language hegemony was reminiscent of the historical situation in Poland. This featured the oppression of minorities with language-based nationalism. I refer to the historical context because research-based evidence to back speculations about language penetration, oppression and resistance was simply never bought to bare within his research framework. But the terms were indicative of Smolicz's political discourse on European and Australian multiculturalism. As I will explain below, the researcher was selective in the groups he supported. He did not interpret all ethnic minorities as equal in terms of their language identity rights but sought to assert the rights of just four migrant groups, including his own, for the allocation LOTE education funding (Smolicz, 1991). In his range of writings, he asserted certain ethnic rights over others, while simultaneously claiming that Australia was vulnerable to the threat of language hegemony because of the widespread teaching of English. Core Values theory was no blueprint for equality and diversity among cultures.

\subsection{Core Values and 'Language Centred' Ethnic Groups}

Core Values theory was based on research on 'language activation' among cultural groups. Like Smolicz's theories of the 
Classification of Social Systems and Ideological Values and Social Systems in Different Societies (Smolicz in Halas, 2002), the connection between research data and theory was thin. Stating that he was drawing on the cultural science theory of Florien Znaniecki that described multifaceted cultural identities among people (Smolicz 1991, p.37), Smolicz claimed that his theory of Core Values had established that some cultures were more language-centred than others (Smolicz, 1981a; Smolicz and Secombe, 1989, in Smolicz, 1991):

The theory of core values argues that some ethnic groups are more language-centred than others, and that for some nations other cultural factors, such as a specific religion, social structure or racial affiliation may prove of greater significance than language (Smolicz, 1981a; Smolicz and Secombe, 1989)

(Smolicz, 1991, p.38).

Thus, Smolicz focused on elevating language values among other values as a research interest. He then proposed that only certain ethnic groups held language as their primary core value and symbol of ethnic identity (Smolicz in Halas, 2002). In Native Tongues and Family Structures as Symbols of Ethnic Identity, (Smolicz in Halas, 2002) Smolicz grafted onto this idea, family values spanning an entire ethnic group. Hence, not only were certain minority ethnic groups more entitled to assert their language rights for education funding than others, their entire ethnic groups were theorised as primary members of their family groups. One wonders whether this project of selective multiculturalism was so idealistic as to be designed to lubricate the doors of the Australian migration department for family reunion visas for just five key ethnic groups, en masse. It should be noted that Smolicz often made conciliatory statements about the subjectivity of the data he presented and the need to avoid generalisations of his models. Exceptional cases could always be assumed. Yet he did not practice this ethos when asserting his theoretical developments in the education policy arena, combining his research-based claims with political discourse to influence education funding at a national level, as is shown below.

Having established the theoretical basis for Core Values to propose the notion of 'language-centred' ethnic groups, Smolicz went on to assert that he had identified those certain cultural groups that were more 'language-centred' than others. This idea can be traced as far back as 1989 in Types of Language Activation in an Ethnically Plural Society (Smolicz and Secombe in Ammon, 1989). This research is reviewed below, but the linkage to the notion of survival is important to note, because it connects Smolicz's theory and ideas about the threat of language hegemony to Australian society to education funding and the needs of selected ethnic groups:

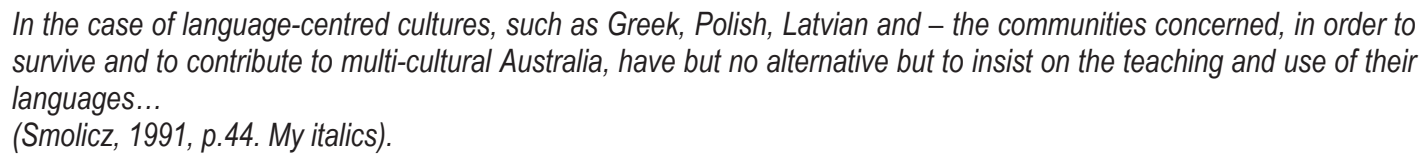

Insisting their languages become taught was a curious strategy in a paper where Smolicz had introduced his discussion with a parody on the threat of language hegemony. Perhaps later Smolicz softened his stance, realising that policy makers just weren't catching on to his research-based conclusions. Certainly the statement was at odds with the idealism he expressed later, as I mentioned above, in justifying his theory on Ideological Values and Social Systems in Different Societies, he spoke of 'a more intimate ethnic complexion' that 'radiated out... to the ethnic groups as a whole' (Smolicz in Halas, 2002, p.113). At this time, Smolicz seemed to have softened his stance, urging minorities who had not claimed language rights to 'coordinate their efforts' in order to do so (Smolicz and Secombe, 2002, p.4) whether their culture was language-centred or not. Despite the fuzzy conceptualisation behind collective ideological values (Smolicz in Halas, 2002), in naming the four language-centred cultures and arguing the cultural costs of assimilation to ethnic groups, Smolicz had already put forward a study by Perlez (1989 in Smolicz, 1991) as an example of what might happen to Australian society if language rights recognition (through LOTE education funding) for his language-centred cultures was not forthcoming. He described a violent incident in Soweto in South Africa that followed a protest by Black students against lessons taught in Afrikaans. Smolicz interpreted Perlez (1989 in Smolicz, 1991),

It was the imposition of the dominant tongue upon unwilling subordinate ethnic groups that triggered riots in which 575 people were killed. In Australia, this frustration has been felt most keenly...'

(Smolicz, 1991, p.44).

by Indigenous Australians. No references were provided for this frustration, which was on the tipping-point of violence. The reconciliation work of by Fesl (1988, in Smolicz 2002) was referred to, concerning language loss and/or an address on multiculturalism (I cannot say which work as there was a referencing error in the paper, with two references 
provided for Fesl, 1988). Smolicz went on to advise readers,

The European and Asian derived minority communities in Australia would prefer to safeguard themselves against a similar fate,

(Smolicz, 1991, p.44-45).

Comparing the process of native language loss due to voluntary migration to Australia with the genocide of the Indigenous community carried out by early settlers of British origin, Smolicz was implying that migrant culture would be wiped out or worse: racial violence and deaths would ensue due to native language oppression.

Perhaps the researcher wished to provoke for the four ethnic groups he had mentioned, the receipt of urgent, prioritised native language teaching resources to be integrated into existing LOTE (Languages Other Than English) programs in primary and secondary schools across Australia and perhaps also through the national English teaching schemes in adult migrants education. He had, after all, just claimed the cultures were on the verge of extinction (Smolicz, 1991, p.44). Or perhaps he was just stirring the pot with rhetoric, hoping to shake things up for fear of large-scale racial or cultural-based violence in Australia. Smolicz's association between language loss due the migration process with the losses experienced by Indigenous Australians was not well informed or substantiated. It is curious that Smolicz could not pay credence to the rapid rise to the middle classes of second-generation migrants in Australia whose parents had arrived impoverished (Colic-Piesker, 2011) which serves as motivation for new arrivals today, while Indigenous Australians still struggled with basic life expectancy in Australia (Australian Institute of Health and Welfare, 2011). Never far away from the discussion about symbols of identity, the use of this argument by Smolicz was double-edged. Using an example of Blacks rising up against the requirement to attend class in the dominant language, Smolicz was expressing (as he often did) his dislike for English as the main language medium in Australia. He seemed to be saying that if the core values of minorities were not respected and language teaching was not funded for the four ethnic groups he had mentioned, Australia's civil society would collapse. Simultaneously, the picture painted of Indigenous discontent leading to race-based violence in schools was divisive. But this was political discourse, not research-based theory on values.

To summarise, Smolicz's selective multiculturalism involved two repeating themes in his work: the prioritisation of native language teaching for particular ethnic groups he termed 'language-centred' based on his Core Values theory (Smolicz and Secombe 1989; Smolicz, 1991, p.4), and concern for the need of ethnic groups to resist assimilating forces, usually associated with the teaching of English language (Smolicz and Secombe, 1989; Smolicz, 1991; Smolicz et al., 2001). The reduction and comparison of the issues experienced by Indigenous Australians with migrants to Australia was not founded in research but political rhetoric. Having explained the connection between Core Values theory and Smolicz's selective multiculturalism, I will now explore the research basis for Core Values in one of the two studies Smolicz stated was the origin of his theory, Types of Language Activation in an Ethnically Plural Society (Smolicz and Secombe, 1989).

\subsection{Justification for Selective Multiculturalism}

In Types of Language Activation in an Ethnically Plural Society (Smolicz and Secombe, 1989), the researchers investigated core values of participants. People of various nationality backgrounds were included in the data, among them Greek, Italian, Croatian, Polish, Latvian, Ukrainian, Welsh, Sinhalese/Tamil (apparently Indian) and Chinese speaking respondents. In one section of the study, a self-report questionnaire called the Core Values Questionnaire (section 10 of the report) was administered across 442 respondents from five different cultural backgrounds, including Greek, Italian, Polish, Latvian and Croatian.

The researchers found that,

Asked which aspect of their culture they considered to be vital for the survival of their group in a plural society, the greatest percentage of respondents claimed speaking their ethnic tongue was vitally important

(Smolicz and Secombe, 1989, p.506. My italics.).

This finding became the basis of Core Values: the self-reported, self-identification of people with their native language as vitally important. The claim to have established particular language centred cultures arose from these findings. Respondents simply answered in the affirmative when being questioned about their opinion as to whether or not they felt their first language was' vitally important' to their survival. The wording of the question may have been the basis for Smolicz's turn of phrase I described above, when he referred to the need for certain ethnic groups to 'insist' their 
native language be taught '...to survive.' (Smolicz 1991, p.44. My italics.).

Another aspect of the research findings was of significance to subsequent claims in Native Tongues and Family Structures as Symbols of Ethnic identity (Smolicz in Halas, 2002). Regarding the use of native language, Smolicz and Secombe (1989) reported that,

\begin{abstract}
Among the Latvians, Ukrainians and the Hobart Polish, reading and writing was the aspect of culture that ranked second to speaking their language. For the Melbourne Polish respondents, Greeks and Croatians, literacy skills came after such aspects as maintaining family ties

(Smolicz and Secombe, 1989, p.506).
\end{abstract}

The results are significant because the researchers identified herein that family relationships are the core value for Polish and Greek (and Croatian) respondents, with language lower than family relationships. According to their own research findings, the core value for Polish and Greek respondents was family, not their native language. Remember that Smolicz's definition of 'language-centred' came from Core Values theory (Smolicz, 1991, p.38), where a number of variables were analysed comparatively. Language was one of the possible variables. Family and religion were others (Smolicz, 2002 in Halas). According to his own system of analysis and the findings in Types of Language Activation in an Ethnically Plural Society, (Smolicz and Secombe, 1989) Smolicz should have reported the Polish and Greek ethnic groups 'family-centred,' not 'language-centred.' This throws doubt on Smolicz's assertion in Language Core Values in a Multicultural Setting (Smolicz, 1991) the four ethnic groups he identified were primarily 'language-centred' cultures compared to other groups (and compared to family or religion as the primary core value of a culture). Although Smolicz then theorised that two or three such variables could be included in core values and this allowed the selected ethnicities to be included as 'language-centred,' it did not account for members of ethnic groups that the researchers had not studied who might also have such a claim. Therefore, the findings (Smolicz and Secombe, 1989) did not justify the claim that these cultures were more language-centred than others. Nor did it justify the strategy of selective prioritisation of these ethnic groups in Australian languages education policy, based on Core Values theory, as argued in Language Core Values in a Multicultural Setting (Smolicz, 1991).

In terms of language activation, the paper concluded that the results,

Lend support to the contention that the maintenance of a minority language is related to whether or not the members of the group recognise their language as the core value of their culture....

Almost certainly conclude the fact that almost all these respondents were, by the very nature of the way the investigation was carried out, actively involved in the life of their ethnic group

(Smolicz and Secombe, 1989, p.508).

The researcher's conclusion highlighted language maintenance was related to self-recognition of a language as the core value among a number of values. The conclusion is another reason to wonder about the later claim that Polish and Greek respondents were 'language centred,' because it did not discuss any particular ethnic group as having language centred values. It did not mention 'language centred' groups at all. All respondents were considered actively associated with their ethnic groups: not only the five ethnic groups studied using the questionnaire, but also the Ukrainian, Welsh, Sinhalese/Tamil and Chinese speaking respondents in other parts of the study. The assertion by Smolicz that this research and just one other paper helped form the basis of his claim that people belonging to Greek, Polish, and Latvian and Vietnamese ethnic groups belonged to 'language centred cultures' (Smolicz, 1991, p.44) is quite difficult to substantiate.

\title{
3.3 Selective Multiculturalism and Australian Language Policy
}

In Language Core Values in a Multicultural Setting: An Australian Experience (Smolicz, 1991, p.35), Smolicz explored the fear of 'hegemony' of the English language and the threat of 'linguistic uniformity' in Australia. He developed this argument by distinguishing Australian language policy in contrast to European countries on the basis that in Europe there was no 'mainstream' language in use, while within Australia's 'overarching framework of values' English was a shared language (Smolicz, 1991, p.35-36). Smolicz's speculations of language hegemony were, it seems, inspired by his own research that simply recognised a broad value for the English language self-reported among research participants. While Smolicz (in Halas, 2002) was capable of understanding the difference between the nation, state and culture, he persisted 
in ascribing national labels to ethnic groups and languages. He described the Greek migrant culture as unique in successfully 'resisting the assimilationist pressures of the mainstream society' (Smolicz in Halas 2002, p.120) because they maintained their cultural identity. Thus, Smolicz equated the recognition of ethnic identity with resistance to language oppression of a nationalist persuasion.

As far as I could ascertain and as I have explained, the assumption about language oppression was projected from the anti-assimilationist political discourse onto the research discussion, not the other way around. This gives cause to wonder about the claim to an inductive research approach via humanistic sociology. Neither Ozolins (2003) or Rubino (2011), who evaluated Smolicz's work (in brief), discussed data collected on cultural oppression generally, or language oppression in particular. It appears that merely the existence of English as the language of the dominant, monolingual culture and language loss found amongst second and third generation migrants (a normal feature of permanent migration) was enough to satisfy the presence of language oppression, while the teaching of just one LOTE (Language Other Than English) per ethnic group was seen to be the necessary preserver of cultural identity to ensure the survival of vulnerable groups (Smolicz, 1991).

Smolicz's vision of language education policy was always looking back toward the European nationalist movements that shaped his early life, ethnic conflict, political oppression and forced assimilation including language rights abuses (Secombe and Zadja, 1999; Smolicz, 1971; Smolicz, 1991; Smolicz, 2002). His commitment to the social justice basis for teaching LOTE was limited by his inability to conceive language learning programs for all Australian students or that the prospect that migrant education in Australia was not solely predicated on cultural loss. But this prospect may have challenged an ideology that imagined the 'penetration' of English language into family life (Smolicz in Halas, 2002, p.119) and the need for 'resisting the assimilationist pressures of the mainstream society' (Smolicz in Halas 2002, p.120).

Ozolins (1993) analysed Smolicz's politics critically, accounting for the intellectual climate of the times more than his research claims. His milieu was a climate of backlash and racist sentiment toward the very concept of multiculturalism. Ozolins (1993, p.107, cited the on-going resistance to the use of the term integration compared to assimilation. The latter term was favoured due to its implication of loss of identity and culture. Ozolins believed that Smolicz had started out appropriating the term for its negative value in Is the Australian School an Assimilationist Agency? (Smolicz, 1971) where he claimed Australian schools were deliberately eradicating migrant cultures and languages. Secombe and Zajda (1999) went on to republish these ideas. Smolicz summed up his attitude to multiculturalism,

Under the guise of multiculturalism, the goals of assimilation can then be brought nearer without incurring the odium of denying cultural rights to the minorities.

(Smolicz in Secombe and Zadja 1999, p.53)

Smolicz's political ideology provokes cause to wonder why he was so sure about the denial of language and cultural rights to whole ethnic minority groups in Australia. The conclusions of Core Values, that certain 'language centred' ethnicities could not survive forced assimilation (Smolicz, 1991; Smolicz in Halas, 2002) went part-in-parcel with the Australian schools system that denied language and cultural rights (Smolicz, 1971, Secombe and Zajda, 1999). It is widely understood within the field of social science that theory is not always supported with a perfect match with data in qualitative studies (Burgess, 1986) yet Smolicz departed from key ideas championed by Florien Znaniecki (1934) emphasising close and rigorous analysis of data from which theory would arise.

While conceding that exceptions were always possible (Smolicz in Halas, 2002), the theoretical frameworks in Core Values (Smolicz, 1991), the Classification of Social Systems and Ideological Values and Social Systems in Different Societies (Smolicz in Halas, 2002) were put forward as general systems of classification and ascribed to whole ethnic populations. Smolicz 'pushed the envelope' in applying so broadly his conclusions from collections of small-scale qualitative research studies including a not insubstantial collection of unpublished data about which little or no information was offered (around $40 \%$ of the data). The situation where the results of unpublished studies were continually used to promote new theoretical developments in the field, is worth further exploration (but beyond the scope of this article). For a researcher who consistently claimed to use the inductive, humanistic sociology of Florien Znaniecki, Smolicz's concurrent, ambitious political discourse on minority unrest and the eradication of culture in the Australian education system cast a heavy shadow over the research participant's viewpoints. Iser's clarification comes to mind in considering this project of selective multiculturalism:

'Discourse is deterministic, whereas theory is explorative.'

(Iser, 2006, p.12) 
Smolicz believed that students from minority ethnic groups were more vulnerable than others if their first language was their core value (Smolicz in Halas, 2002, p.123). However, most proponents of language education today would agree that migrants groups who value and use their first language in any measure have an intellectual and cultural advantage (Lo Bianco and Slaughter, 2009). The cultural and linguistic advantages for bilingual and multilingual students is recognised as a key driver in LOTE uptake and maintenance. The failure of in-school teaching programs for students who do not speak the same second language at home has also been recognised (Lo Bianco and Slaughter, 2009). The position of English as the global lingua franca is well established, while the current national educational priority is to ensure that Australian students, whatever their cultural background, can speak, read and write English as well as their counterparts from other parts of the globe (Herscovitch, 2009). In hindsight, Smolicz's ideology reflects the growth of multiculturalism in Australia during the 1970s and 1980s, a time when 'multicultural language ideology in... Australia was an undisputed world leader' (Lo Bianco, 2009, p.19 citing Clyne, 1991; Ozolins, 1993; Ozolins, 2001). The current focus is on recovering lost ground in standard literacy skills for every person, now that a recognition of the positive, normalised state of language transmission and maintenance among members of ethnic communities has been achieved (Herscovitch, 2012). As for the Polish ethnic group (his own) that Smolicz expressed concerned about in Core Values theory (Smolicz, 1991, p.44) a recent, comprehensive research paper by Markowski and Williams (2013) found that,

Overall, Polish immigrants have blended well into the broader Australian community and represent the type of immigrant stream that Australian policy makers have long tried to attract. This is because in comparison with many other immigrant groups, Polish immigrants have been ready to embrace the national identity of the Australian host community and have not found it difficult to combine their old and new identities.

(Markowski and Williams, 2013, p.1. My Italics.)

Perhaps Smolicz could take some credit for this success. Debates in multiculturalism have evolved and shifted to deal with the realities of transnational migration, a model that conceives of migrant communities enriched and empowered by their on-going links with their home country, culture and first language. Generous education and social support benefits made available to new migrants are now widely known, while the 'family reunion' basis for large migrant networks to reach Australia using these pathways has been restricted (Australian Refugee Council, 2012). This is not to say asylum seekers receive appropriate treatment in response to their attempts to migrate, especially those classed Irregular Maritime Arrivals who arrive by boat. But they compete with the influx of international students in Australian schools and universities, who are supported by academic language programs and the provision of a range of other inhouse services not available to Australian students. This has changed the Australian education scene substantially. Much of the social welfare model of language instruction in Australia is becoming rapidly irrelevant to policymakers as schools close down their LOTE classes or shift from European languages to Asian ones, while universities redirect their departments towards facilitating overseas, native-speaking, fee-paying, degree and 'short course' clients. It is now widely understood that equality and diversity are not entirely compatible in the Australian education system but that tensions exist between them for,

Equality requires a common yardstick, or measure of judgement, not a plurality of meanings (Malik, 2002, p.1).

\section{Concluding Remarks}

This paper analysed two areas of theoretical development in humanistic sociology and cultural studies proposed by social scientist Jerzy Smolicz. They included Symbols of Ethnic Identity (Smolicz in Halas, 2002) and Core Values theory (Smolicz, 1991). In Symbols of Ethnic Identity, the researcher proposed two frameworks, the Classification of Social Systems and Ideological Values and Social Systems in Different Societies (individualist and collectivist ideology) (Smolicz in Halas, 2002). A review of the theory-building process indicated that the strength of the claims was weaker than one might expect, with some areas were more speculative than evidence-based. Moreover, the political discourse in which Smolicz engaged carved out a selective multiculturalism, elevating the cultural and language rights claims of some ethnic groups over others. This raises questions about the application of the theory to ethnic minority groups and Australian society, and the extent to which the research was inductive in the tradition of Florien Znaniecki's (1969) humanistic sociology. The work serves as a snapshot in time that reveals much about the influence of educational researchers on the development of Australia's language policy in schools, with a more dynamic, reciprocal and authentic vision of cultural identity emerging. 


\section{References}

Australian Institute of Health and Welfare (2011). The Health and Welfare of Australia's Aboriginal and Torres Strait Islander people: an overview 2011. Canberra.

Australian Refugee Council (2012). Humanitarian Family Reunion: The Building Block of Good Settlement. April, 2012. Sydney: RCOA.

Burgess, R. (1986). Key Variables in Sociological Investigation. London: Routledge and Kegan Paul.

Clyne, M. (2005). Australia's Language Potential. University of New South Wales Press.

Colic-Peisker, V. (2011). A New Era in Australian Multiculturalism? From Working-Class 'Ethnics' To a 'Multicultural Middle-Class. International Migration Review 45, 562-587.

Foster, L. E. and Stockley, D. (1988). Australian Multiculturalism: A Documentary History and Critique. Avon: Multilingual Matters Ltd.

Hofstede, G. (1994). Cultures and Organisations: Intercultural Cooperation and its Importance for Survival. London: Harper Collins.

Ingram, D. E. (2003). English Language Policy in Australia. Conference paper, Summer International Conference of the Korea Association of Teachers of English (KATE): Chungnam National University, Korea.

Iser, W. (2006). How To Do Theory. Malden: Blackwell Publishing.

Lagasabaster, D. (2010). Australia's Language Potential. International Journal of Multilingualism 7 (2), 187-190.

Lo Bianco, J. (1987). National Policy on Languages. Canberra: Australian Government Publishing Service.

Lo Bianco, J. and Slaughter, Y. (2009). Second Languages and Australian Schooling. Camberwell: Australian Council for Educational Research.

McMeniman, M. (1988). A theoretical analysis of second language dropout. Journal of the Australian Federation of Modern Language Teachers' Association, Volume 1 (232), 16-22.

Malik, K. (2002). Against Multiculturalism. New Humanist (Summer).

Markowski, S. and Williams, K. (2013). Australian Polonia: A Diaspora on the Wane? Central and European Migration Review. Warsaw: Centre of Migration Research, University of Warsaw.

Ozolins, U. (1993). The Politics of Language in Australia. Cambridge: Cambridge University Press.

Secombe, M. J. and Zajda, J.I., eds. (1999). J.J. Smolicz on Education and Culture. Albert Park: James Nichols Publishers.

Smolicz, J. J. (1971). Is the Australian School an Assimilationist Agency? Education News 13 (4), 4-8.

Smolicz, J. J. (1984). Multiculturalism and Overarching Framework of Values: Some Educational Responses for Ethnically Plural Societies. European Journal of Education 19(1), 11-23.

Smolicz, J. J. (1986). National Policy on Languages: A Community Language Perspective. Australian Journal of Education, 30 (April), $45-65$.

Smolicz, J. J. (1991). Language Core Values in a Multicultural Setting: An Australian Experience. International Review of Education, $37(1), 33-52$

Smolicz, J. J. (2002). Native Tongues and Family Structures as Symbols of Ethnic Identity in Halas, E. Symbols, Power and Politics. Frankfurt: Peter Lang.

Smolicz, J.J. and Secombe, M.J. (1985a). Polish Culture and Education in Australia: A Review of Some Recent Research and Educational Developments, in Sussex, R. and Zubrzycki (eds.). Polish People and Culture in Australia. Canberra: Australian National University.

Smolicz, J. J. and Secombe, M. J. (1985b). Community Languages, Core Values and Cultural Maintenance: The Australian Experience with Special Reference to Greek, Latvian and Polish Groups in Clyne, M. (ed.) Australia - Meeting Place of Languages. Canberra: Pacific Linguistics, Australian National University.

Smolicz, J. J. and Secombe, M. J. (1986). Italian language and culture in South Australia: A memoir approach. In C. Bettoni (ed.) Altro Polo: Italians Abroad: Studies on Language Contacts in English Speaking Countries. Sydney: Frederick May Foundation for Italian Studies.

Smolicz, J. J. and Secombe, M. J. (1989). Types of Language Activation in an Ethnically Plural Society. In U. Ammon, ed. Status and Function of Languages and Language Varieties. Berlin and New York: de Gruyter.

Smolicz, J. J. and Secombe, M. J. (2002). Assimilation or Pluralism? Changing Policies for Minority Languages Education in Australia. Language Policy. April 2003 2(3), 3-25.

Smolicz, J.J. and Secombe, M.J. \& Hudson, D.M. (2001). Family Collectivism and Minority Languages as Core Values of Culture Among Ethnic Groups in Australia. Journal of Multilingual and Multicultural Development, 22(2), 152-172.

Znaniecki, F. (1934). The Method of Sociology. New York: Farrar and Reinhart

Znaniecki, F. (1952). Cultural Sciences, Their Origin and Development. Urbana: University of Illinois Press.

Znaniecki, F. (1952). Modern nationalities: A Sociological Study. Urbana: University of Illinois Press.

Znaniecki, F. (1969). Florien Znaniecki On Humanistic Sociology. Bierstedt, R. (ed.) Chicago: Chicago University Press. 
